\title{
Development of a Reference Handbook Based on Contextual Teaching Learning in Curriculum Studies Course
}

\author{
Beta Wulan Febriana ${ }^{a, *}$, Widinda Normalia Arliantya \\ ${ }^{a}$ Department of Chemistry Education, Islamic University of Indonesia \\ *Corresponding author: betawulanfebriana@uii.ac.id
}

\begin{abstract}
The study aims to find out the implementation of reference handbook based on CTL. Design of the study is a modified Research and Development (R\&D) developed by Borg and Gall. Subjects in this study are students of Chemical Education Major in Islamic University of Indonesia in the odd semester of academic year 2016/2017. The reference handbook arranged has been validated by academics and practitioners and categorized as "Very Good" with score 92.29\% and 92.09\% respectively. Furthermore, the reference handbook was also tested in the Preliminary Field Testing phase and scored $88.89 \%$ with the category "Very Good". After the reference handbook was revised following the phase, it was re-tested at the Main Field Testing phase and scored $89.09 \%$ with the category "Very Good". Based on these results, the reference handbook has been developed can be implemented in the Curriculum Studies course very well.
\end{abstract}

Keywords: curriculum studies, contextual teaching and learning (CTL), reference handbook

\section{INTRODUCTION}

Curriculum has an important role in education in Indonesia. The curriculum determines the direction and purpose in an education system. Not infrequently, the curriculum maychange according to the purpose of a country. The curriculum can be changed according to the strategic plan implemented in a country.

Indonesia has undergone several changes in the curriculum, start from Competency-Based Curriculum (KBK), Education Unit Level Curriculum (KTSP) to Curriculum 2013 (K-13). The curriculum occupies a central position in the educational process. Changes that occurred in the curriculum would affect the learning process in school.

Curriculum studies must be studied by students of prospective teachers. This course focuses on how the curriculum was made, how the curriculum changes over time, and the objectives of the curriculum. Students must be able to analyze the changes in the curriculum, analyzing chemistry textbooks in schools are that already in line with the curriculum 2013 or not.

The presence of Contextual Teaching and Learning (CTL)-based reference handbook is able to assist prospective teachers in analyzing curriculum changes. The reference handbook contains models in developing the curriculum, government regulation related on the KBK, KTSP and K-13, and how the implementation of the curriculum is happening in some schools in Yogyakarta.

The CTL-based reference handbook is expected to allow students of prospective chemistry teachers to be motivated in analyzing the curriculum. The reference handbook can assist students in studying and analyzing curriculum structures and analyzing textbook content. In addition, students can easily learn curriculum materials wherever they want.

Approach of CTL coupled with the use of the handbook requires students to take action in school. By doing the action, the student will indirectly always remember the activities that have been done. Such process of knowledge finding becomes more meaningful if it is continued with the existence of analysis activities. In addition, learning of CTL helps students to manifest the curriculum studies which is theoretical in nature.

The developed CTL-based reference handbook is able to bring students into real situations in school. Students are familiarized with the competencies that must be mastered by high school students. Moreover, students are required to read various textbooks that high school students use in schools. 
Finally, students will find out which textbook is good and match with the expectations of currrent curriculum.

Mulyasa argued that teaching materials is one of the teaching resources that can be interpreted as something that contains learning messages, both specific and general in nature that can be utilized for the benefit of learning [1]. Dick, Carey, and Carey added that the teaching materials contain contents that are written, mediated, or facilitated by teachers that students use to achieve a goal including information that students will use to achieve an improvement [2].

Teaching materials is a print-based learning media that can improve student learning motivation. Febriana revealed that the motivation to learn arise because the interest of students on the module developed. Indirectly, this will also affect the increasing achievement of learning [3].

Learning with contextual approach has the following characteristics [4]: 1) Learning is carried out in an authentic context, that means learning is directed towards the attainment of skills in a real-life context or learning is carried out in a natural environment, 2) Learning provides opportunities for students to do meaningful tasks, 3) Learning is done by providing meaningful experiences to students, 4) Learning is done through group work, discussion, mutual correction among friends, 5). Learning provides opportunities to create a sense of togetherness, work together, and understand each other in depth, 6) Learning is carried out actively, creatively, productively and emphasizes work together, 7) Learning is done in a fun situation.

\section{METHOD}

\section{Research design}

The research design was Research and Development (R\&D) model that developed by Borg and Gall consisting of ten stages [5]. The tenth stage of Borg and Gall is limited to the sixth stage, which is 1) research and information collecting, 2) planning, 3) develop preliminary from product, 4) preliminary field testing, 5) main product revision, and 6) main field testing. Stages in this study can be briefly seen in Figure 1.

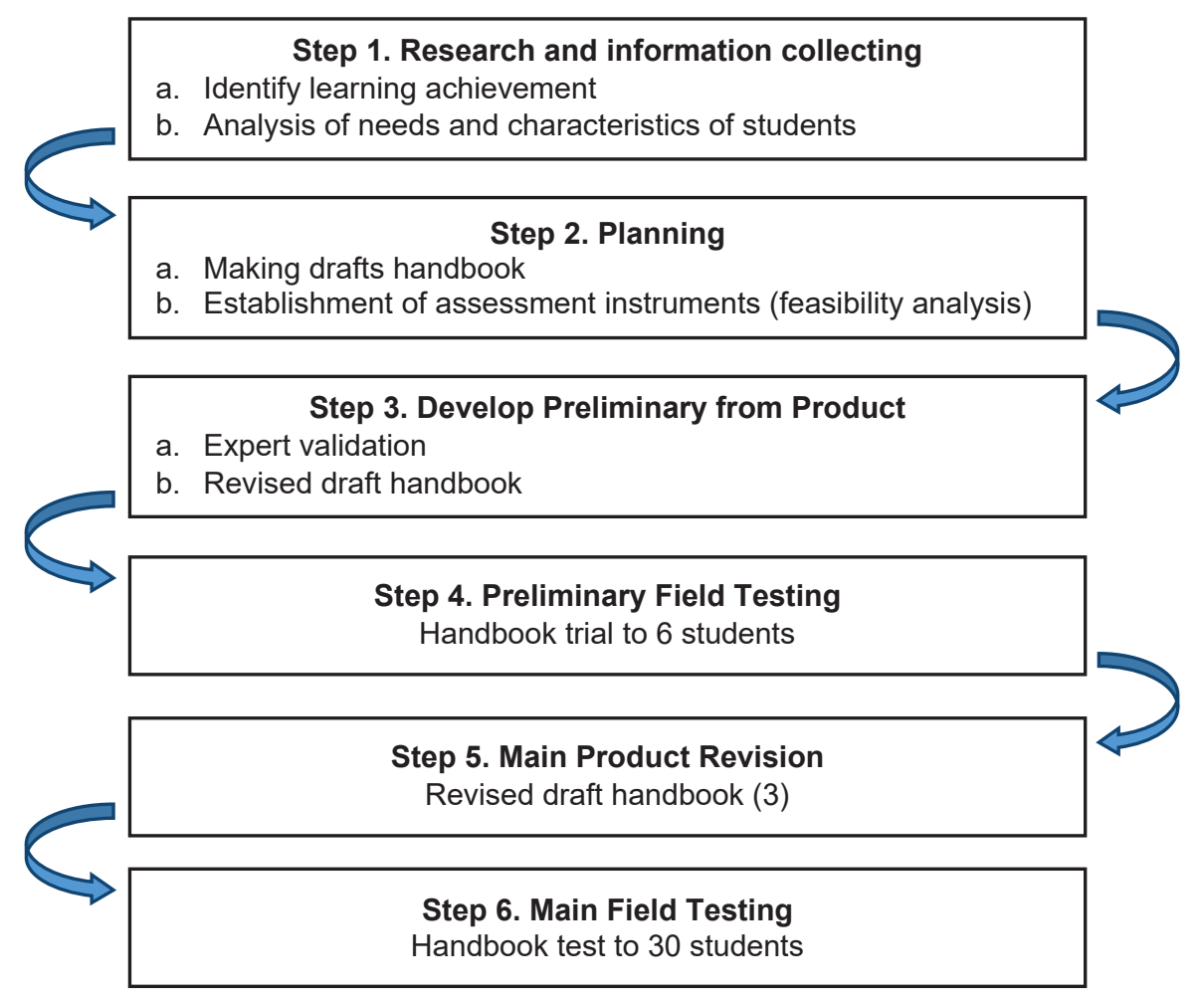

FIGURE 1. Research and Development design by Borg and Gall 


\section{Place, Time and Subject Research}

The research was conducted in Faculty of Mathematics and Natural Sciences, Islamic University of Indonesia. Subjects in this research are Chemistry Education students in the fifth semester.

\section{Data Collection}

Data collection techniques used non-test methods. Data collection techniques used are data from the observation and questionnaire. Observational data were obtained from interviews with several Chemistry Education students.

\section{Research Instruments}

The research instrument used a judgement expert sheet and a student response questionnaire. The instrument that used to a judgement expert sheet applies criteria established by the National Education Standard Board (Badan Standar Nasional Pendidikan-BSNP). Teaching Materials Assessment criteria [6] including,

1. Content Aspect

2. Presentation Aspect

3. Readability Aspect

4. Graffity Aspect

\section{Data Analysis}

Data analysis technique used is quantitative descriptive analysis by describing the product development result that has been made. Data obtained through questionnaires from material experts and student responses then the quantitative data transformed into qualitative data. Based on the results of expert validation assessment and questionnaire of student's response can be known feasibility of handbook that has been made. Instrument criteria using Widoyoko's [7] is as follows,

TABLE 1. Assessment Scale Criteria

\begin{tabular}{ccc}
\hline Category & Grade & Percentage (\%) \\
\hline Very Good & 4 & $76-100$ \\
Good & 3 & $51-75$ \\
Not Good & 2 & $26-50$ \\
Not Very Good & 1 & $0-25$ \\
\hline
\end{tabular}

\section{RESULTS AND DISCUSSION}

The purpose of this research is to develop a reference handbook based on CTL for chemistry curriculum study course. The development of handbook that has been done using six stages, namely 1) research and information collecting, 2) planning, 3) develop preliminary from product, 4) preliminary field testing, 5) main product revision, and 6) main field testing. Based on the results of research that has been done, exploration of each stage is as follows,

\section{Research and Information Collecting}

At this stage, it is obtained information related to the achievement of learning that must be mastered by students. The researcher found one of the problems that exist, that is the unavailability of handbook that is able to assist students in studying curriculum studies subject. Based on this problem, it is necessary to develop a handbook as teaching materials that help students in studying and analyzing the curriculums exist in Indonesia and distinguish chemistry textbook for upper secondary school/vocational high school/Islamic high school in accordance with Curriculum 2013.

Based on the requirements analysis and student characteristics analysis, there are some cases become the main point, as follows: Chemistry Education students like a textbook which is full color, rather than full of text, and use of sentences that is easy to understand. Chemical Education students tend to dislike passive learning processes. Most of them like an active learning process. They like the presentation and observation activities.

In this case the researcher developed a handbook contains the materials to guide students in distinguishing between the curriculum structure, learning method, assessment on the KBK, KTSP and 
Curriculum-13. In addition, this handbook is required by students in analyzing chemistry textbooks taught in schools, whether or not it is in accordance with current curriculum guidance. Contextual Teaching and Learning based reference handbook helps students in observation activities to find out whether or not there is a gap of curriculum implementation in some high schools in Yogyakarta with an ideal curriculum.

\section{Planning}

Planning of the handbook arrangement pays attention to the learning achievement of curriculum studies subject contained in the curriculum of National Indonesia Qualification Framework (Kerangka Kualifikasi Nasional Indonesia-KKNI). Furthermore, each learning activity that will be done is adjusted to Semester Learning Plan (Rencana Pembelajaran Semester-RPS) which is at this stage the handbook consists of three main sections, those are 1) Curriculum Concepts, 2) Curriculum in Indonesia: KBK, KTSP, and Curriculum-13, 3) Chemistry Textbook Feasibility Analysis.

Handbook writing referred to several aspects mentioned by the BSNP, including 1) content aspect, 2) presentation aspect, 3) readability aspect, and 4) graffity aspect. In addition, to stimulate students interest in reading the developed handbook it was added some interesting tables and graphs that facilitate students understanding. Reference handbook was prepared by covering covers, introduction, table of contents, materials, summary, and bibliography.

\section{Develop Preliminary from Product}

This development stage produced a product in the form of handbook which will then be validated by experts. The validation process is done to make the handbook that has been prepared to meet the predefined standards. Handbook is said to be suitable if the percentage of all aspects reached $\geq 61 \%$. Experts validation in charge of reviewing this handbook consists of lecturers and teachers. The assessment standards for the validation process are obtained from the BSNP covering, 1) content aspect, 2) presentation aspect, 3) readability aspect, and 4) graffity aspect.

TABLE 2. Expert Validation Rating Data

\begin{tabular}{llcccc}
\hline \multirow{2}{*}{ Judgement Expert } & \multicolumn{4}{c}{ Rating Result (\%) } \\
\cline { 3 - 5 } & & $\begin{array}{c}\text { Content } \\
\text { Aspect }\end{array}$ & $\begin{array}{c}\text { Presentation } \\
\text { Aspect }\end{array}$ & $\begin{array}{c}\text { Readability } \\
\text { Aspect }\end{array}$ & $\begin{array}{c}\text { Aspect } \\
\text { Graffiti }\end{array}$ \\
\hline Academics & Score & 93.75 & 85.42 & 95.00 & 95.00 \\
& Mean Score & 92.29 & & & \\
& Category & Very good & & 92.50 & \\
\hline Practitioners & Score & 91.67 & 89.58 & \\
& Mean Score & 92.09 & & & \\
& Category & Very good & & & \\
\hline
\end{tabular}

Based on the results of validation by the experts, it was found that the average score obtained $92.00 \%$ with the category of "Very Good." Furthermore, the validated handbook was revised in accordance with suggestions submitted by experts.

\section{Preliminary Field Testing}

At this stage, the revised handbook was tested to nine Chemistry Education students. This assessment used a student response questionnaire that aims to determine how students respond to the handbook that has been developed. Based on the questionnaire of student's response, it was found that the average score obtained was $88.89 \%$ with the category "Very Good" and feasible to use.

\section{Main Product Revision}

Based on the assessment of the response questionnaire it was also obtained suggestions and propositions from students related to the handbook developed. Furthermore, the handbook was revised in accordance with the suggestions and inputs from students. 


\section{Main Field Testing}

The revised handbook in the previous stage was re-tested to students. The number of students who completed this response questionnaires, is 30 people. Based on the students response questionnaires at this stage it was obtained percentage of $89.09 \%$ with category "Very Good."

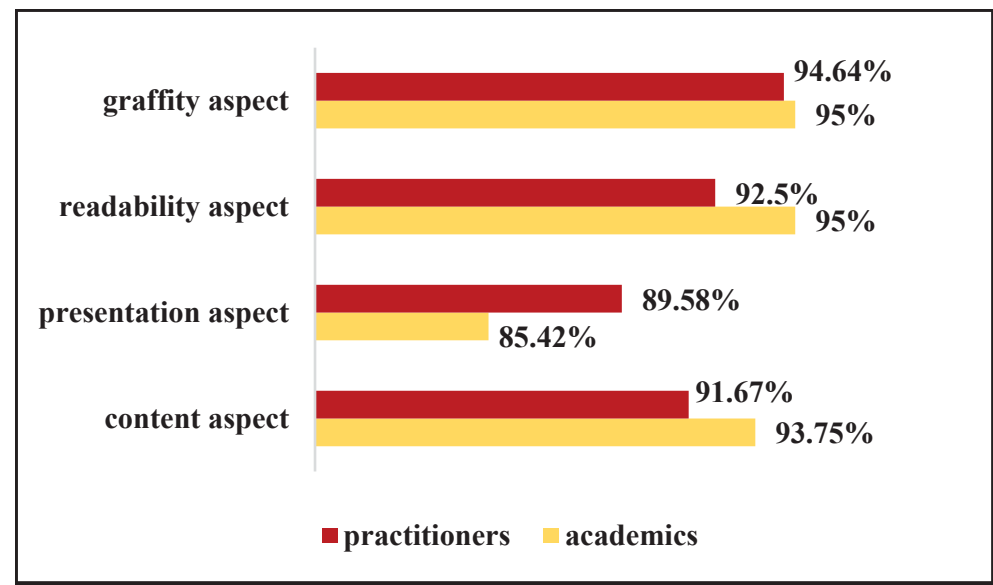

FIGURE 2. Expert judgement validation results

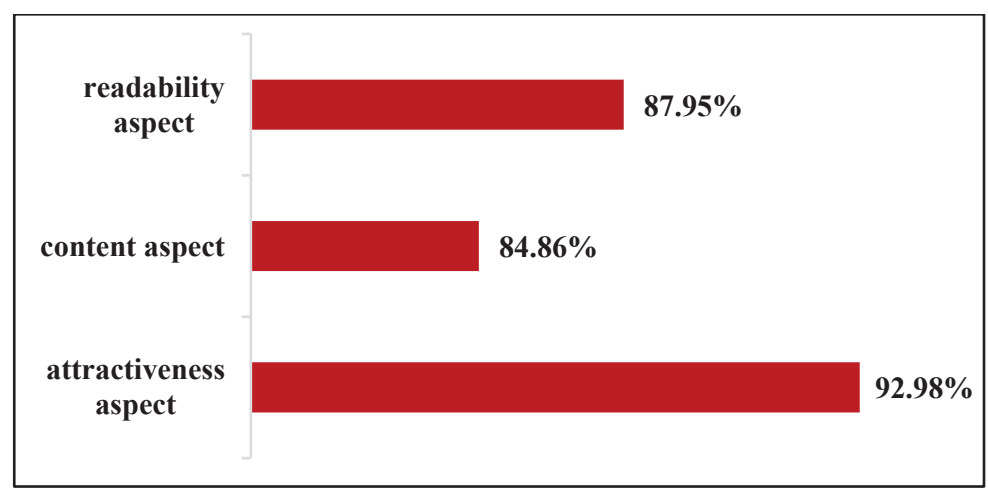

FIGURE 3. Result of student response questionnaire

The results of this study indicated that CTL-based reference handbook reached the category "very good" and feasible to use. The use of this Curriculum Studies handbook must be supported by the use of CTL learning approach so that the handbook can be used effectively and appropriately.

Teaching materials is a very important part of the learning system. Developing the teaching materials was in the form of a handbook with a CTL learning approach. Thus, students have an important role in understanding the curriculum concepts, curriculum principles, curriculum development process and problem solving provided that is tailored to real life. Based on Nurhadi et al, correct learning should be emphasized on helping students to learn how to learn, rather than emphasizing as much information as possible at the end of the learning period [8].

The validation results by the experts showed that the developed handbook is worthy of use under the category of "Very Good." The validation process used BSNP assessment standards that include, 1) content aspect, 2) presentation aspect, 3) readability aspect, and 4) graffity aspect. Validation is done by material experts and learning media experts from lecturers and teachers. The results of validation by experts can be seen in Figure 1.

In the test results, students were given a response questionnaire to evaluate handbooks developed based on three aspects of the assessment: 1) content aspect, 2) readability aspect and 3) attractiveness aspect. These three aspects get very good categories as seen in Figure 2. The results prove that the students love the handbooks that have been developed. 
This handbook adapted from Ausubel model about meaningful learning. This Ausubel model put forward deductive reasoning, which is requires students to first learn the principles, then learn to know the specific things of those principles. This approach assumes that one learns well when understood general concepts, advanced deductively from rules or principles to examples [9].

Handbooks developed have been adapted to the standards set by Depdiknas [10], namely adaptive, self-instructional, stand alone, self-contained, and user-friendly. Teaching materials in the form of handbooks can generate student motivation in learning about what he did not know.

\section{CONCLUSION}

A study aimed at developing a CTL-based reference handbook has resulted in a product that has been validated and feasible to use. This reference handbook obtained the "Very Good" category in Preliminary Field Testing with $88.89 \%$ and got "Very Good" with $89.09 \%$ in Main Field Testing.

\section{ACKNOWLEDGMENTS}

The authors wish to thank the Academic Development Board (ADB) of the Islamic University of Indonesia that has provided an opportunity to become a grantee of the Regular Teaching Grants Program in the odd semester of the academic year 2016/2017.

\section{REFERENCES}

1. Mulyasa, Implementasi Kurikulum 2004 Panduan Pembelajaran KBK (Remaja Rosdakarya, Bandung, 2006).

2. W. Dick, L. Carey and J.O. Carey, The Systematic Design of Instruction (Pearson, New Jersey, 2009).

3. B. W. Febriana, Ashadi and M. Masykuri, "Effectiveness of Module Based Problem Based Learning (PBL) Toward Student's Achievement Motivation" in Proceeding of International Seminar on Chemical Education (ISCE) (UII, Yogyakarta, 2015), pp. 30-35.

4. M. Muslich, KTSP Pembelajaran Berbasis Kompetensi dan Kontekstual (Bumi Aksara, Jakarta, 2007).

5. W. R. Borg, and M. D. Gall, Education Research an Introduction (Longman Inc. Choksy, New York, 1983).

6. BSNP, Instrumen Penilaian Buku Teks Pelajaran (http://bsnp-indonesia.org/2014/05/28/instrumenpenilaian-buku-teks-pelajaran-tahun-2014/, 2014).

7. E. P. Widoyoko, Evaluasi Program Pembelajaran (Pustaka Pelajar, Yogyakarta, 2012).

8. Nurhadi, B. Yasin, and A. G. Senduk, Pembelajaran Kontekstual dan Penerapannya Dalam KBK (UM Press, Malang, 2004).

9. D. P. Ausubel, Educational Psychology: a Cognitive View (Holt, Rinehart and Winston, New York, 1968).

10.Depdiknas, Panduan Pengembangan Bahan Ajar, (Direktorat Jenderal Manajemen Pendidikan Dasar dan Menengah, Jakarta, 2008). 